\title{
What difference does the gig mobility service make in the workers' human needs structure?
}

\author{
Markus Hartono $^{\mathrm{a}, *}$, Hendry Raharjo ${ }^{\mathrm{b}}$, I Made Ronyastra ${ }^{\mathrm{a}}$ \\ ${ }^{\text {a }}$ Department of Industrial Engineering, University of Surabaya, Indonesia \\ ${ }^{\mathrm{b}}$ The Division of Service Management and Logistics, Chalmers University of Technology, Sweden
}

\section{A R T I C L E I N F O}

\section{Keywords:}

Mobility service

Human needs

Gig workers

\begin{abstract}
A B S T R A C T
This paper aims to compare and contrast the perceived psychological experience of the traditional versus gig mobility service workers with respect to their human needs structure. Gig mobility service here refers to ondemand transportation service enabled by an online platform. Both qualitative and quantitative research methods were used. Using the perspective of ERG (Existence, Relatedness and Growth) theory, we first explored the field using in-depth interviews and observations of both worker groups. Based on the qualitative findings, we formulated the quantitative measures for the corresponding constructs. The constructs' relationship and paths differences between the two groups were analyzed statistically using partial least square path modeling (PLS-PM) method. The differences between the two groups were categorized into four quadrants, highlighting what both groups have and do not have, as well as what one group has but not the other. It was found that the gig mobility service resulted in not only more relationships among the constructs, but also generally higher perceived wellbeing for the workers. It seems that the gig mobility service has so far been promising in meeting workers human needs despite its long-term uncertainty. This study is among the few studies on understanding in which way the technology has changed the mobility service actors seen as workers, rather than sellers or users.
\end{abstract}

\section{Introduction}

Smartphone apps with geolocation service technology enable online platform to match labour supply and demand. This creates the new world of work (Ashford et al., 2018) in which people, who are called gig-workers, perform a service on-demand often with lower fees for a firm or customer without having a clear employment relationship with the online platform. Their ambiguous employment status (Kuhn and Maleki, 2017) gives rise to the question of their well-being or whether such work practice is socially sustainable. Minimum wages, pension scheme, health insurance, to name a few, are among those benefits which are traded off for working flexibility, increased autonomy, and independence. Kuhn and Maleki (2017) wrote that "Most of the academic research to date ... focused on questions of market optimization, who tend to view the people performing service labour as "sellers" or "users" rather than as workers."

In line with the research to investigate the people performing service labour as workers rather than sellers or users within the context of ondemand economy, we carried out this study to better understand the perceived psychological experience of those workers using human needs perspective. Specifically, we adopted and adapted the ERG (existence, relatedness, and growth) theory by Alderfer (1969). The gig workers in the study are the drivers from the company which is called Go-Car. It is an online based car ridesharing service run by Indonesian first unicorn start-up company called Go-Jek. As of December 2017, there are approximately 15 million active users and more than 100 million transactions per month. Its transactions reached approximately US\$ 12.5 billion during 2018 (Sinintya, 2019). As the baseline for comparison, we selected the traditional counterpart of the same mobility service field, that is, the drivers of traditional taxi company in the same city.

We used both qualitative and quantitative research methods for collecting empirical data from both groups. We aim to compare and contrast the perceived psychological experience of the traditional versus gig mobility service workers with respect to their human needs structure using the ERG theory. In which way does the use of the online platform for mobility service change the mobility service workers' perceived well-being? This knowledge can be useful to better understand the actors of the on-demand business ecosystem since those workers play a key role in creating and delivering successful business values.

In the following sections, we will first review the relevant literature

\footnotetext{
* Corresponding author.

E-mail addresses: markus@staff.ubaya.ac.id (M. Hartono), hendry.raharjo@chalmers.se (H. Raharjo), ronyastra@staff.ubaya.ac.id (I.M. Ronyastra).
} 
and theories (Section 2). In Section 3, the research method will be described. The results and discussions will be provided in Section 4. Finally, Section 5 concludes the study and describes some limitations of the research.

\section{Literature review/theoretical background}

\subsection{Sharing economy}

Sharing economy, a new economic model with forecasted potential global market value at USD 335 billion by 2025, was stimulated by contemporary market forces where demand is growing but with limited supply and advancement in the information and communication technology (Lim, 2020). Digital technology not only enables matching labor supply and demand using online platform, but also optimization of underused assets. Uber and Airbnb are often used for exemplifying this in the context of mobility and hospitality service, respectively. They are argued to contribute to sharing economy practices (Geissinger et al., 2018) although there are still relatively few studies that show how it contributes to social, economic, and environmental sustainability (Sutherland and Jarrahi, 2018; Geissinger et al., 2019).

The gig not only offers working flexibility and increased autonomy in a virtual system when there is no human supervisor who can be biased, but also a virtual community of peers who face similar challenges. Such condition can make people thrive. Jabagi et al. (2019) wrote that the digital platform itself, that is, the IT artefact, can serve as a critical determinant of workers' basic psychological needs (Jabagi et al., 2019). Client interaction, for example interactions with passengers, seems to satisfy workers need for relatedness (Rockmann and Ballinger, 2017). Although Roberts and Zietsma (2018) mentioned that the on-demand workers did construct their desire of belonging to the organization by identifying themselves as driver-partner who collaborate with and should be treated fairly by the organization and customers, they also found that on-demand workers not only lacked the benefits of corporate belonging but also played the role as "driver-bot" delivering a perfectly controlled ride experience.

Platform-enabled gig work, on-demand service performed by individuals upon an immediate request of a firm or consumer without a standard employment relationship offers working flexibility, increased autonomy, and independence. Institutional trust is one factor that characterizes online labor platform work (Kuhn and Maleki, 2017). Specifically, the online platform acts as a third party which fosters trust between buyers and sellers online (Pavlou and Gefen, 2004). Such configuration seems to work well and leads to an increasing number of on-demand workers or gig workers and consumers over the last few years. Sharing economy was also found to promote the integration of users with the community by providing access to vital resources to achieve satisfactory living standards (Davlembayeva et al., 2020).

While the sharing economy has changed the marketplace by providing consumers instantaneous services and a broad range of personalized choices, those corporate platforms have also been described as super-exploiters of labor by offering workers substandard schedule choices, limited worker protections and little to no pathways to promotion and job sustainability (Goldkind and Mcnutt, 2018). Within the context of mobility service, criticism was focused on the well-being aspects of the drivers. Many worker protections (job safety) do not apply and many benefit programs (such as health insurance, paid vacations, pension) are excluded from the work arrangements.

Not all gig service providers are in dire need of living income. According to Schor (2017), in the United States, the providers for Airbnb, RelayRides, and TaskRabbit are highly educated and many have well-paying full-time jobs (Schor, 2017). A closer look at those on-demand workers in Toronto revealed that those are millennials generation and have wealthy family background (Young and Farber, 2019). Furthermore, the diffusion of Uber is widely believed to have led to worsened employment prospects for conventional taxi drivers (Berger et al., 2018).

\subsection{ERG theory and Co-Worker support}

The ERG Theory was proposed to deal with the problem of how need satisfaction was related to need strength (Alderfer, 1969). It assumes that human being has three core needs that they strive to meet. First, existence needs include all the various forms of material and physiological desires such as pay, fringe benefits, and physical working resources. The satisfaction of existence needs may be seen as a zero-sum game. Second, relationship needs include all the needs which involve relationships with significant other people such as family, superiors, co-workers, subordinates, friends and enemies. The satisfaction of the relatedness needs relies upon the willingness from each party to mutually share their thoughts and feeling. Third, growth needs include all the needs which involve a person making creative or productive effects on himself and the environment. The satisfaction comes from engaging problem that require one to utilize one's capacity fully and may well require one to develop additional capacities (Alderfer, 1969).

There are seven major propositions in the ERG Theory, namely: P1 (The less existence needs are satisfied, the more they will be desired); P2 (The less relatedness needs are satisfied, the more existence needs will be desired); P3 (The more existence needs are satisfied, the more relatedness needs will be desired); P4 (The less relatedness needs are satisfied, the more they will be desired); P5 (The less growth needs are satisfied, the more relatedness needs will be desired); P6 (The more relatedness needs are satisfied, the more growth needs will be desired); P7 (The more growth needs are satisfied, the more they will be desired).

Although the main motivation for an employee is to fulfil his/her existence needs, the need for a human interaction in the form of coworker relationship also plays a role towards his/her performance. The relationship between co-worker support, employee performance, and well-being has been observed by Singh et al. (2019), Van Emmerik, Euwema and Bakker (2007), and Rousseau et al. (2009). They showed that good co-worker support is associated with better well-being. Co-worker support was found to have positive association with psychological flourishing, which, in turn, was positively associated with employee performance (Singh et al., 2019). A model proposed by Hon (2012) indicated that supportive co-workers have an important effect on creative performance. For the gig workers, the relationship among peers does not necessarily exist in a formal form compared to the relationship in conventional organizations (Hon, 2012).

\section{Research methods}

This study used empirical data from Go-Jek. It is the first start-up from Indonesia with the title of decacorn. In Indonesia, on-demand service provider company named Go-Jek has contributed IDR 9.9 trillion (USD 670 Million) per year to Indonesia's economy (Setiawan and Ika, 2018). As much as IDR 8.2 trillion (USD 550 Million) came from the income of the driver's partners including Go-Car as one of the Go-Jek services. Go-Car has been reported to offer the following benefits, such as speed, convenience, safety, comfort, and ease of payment (htt ps://www.go-jek.com). Established in 2009, Go-Jek has managed to have more than 1 million drivers as of May 2018. These drivers come from various backgrounds including former informal driver, housewives, university students, employees in private sectors who were attracted to the flexibility and the incentives which may reach around 2.5 times the minimum wage in Indonesia (Paundra et al., 2020).

We used both qualitative and quantitative methods. The qualitative methods were used in the beginning of the research to explore the research phenomenon. In-depth interviews, observations, and immersions were used. Based on the results of the qualitative study and existing theories, the quantitative research methods were used. Specifically, two batches of surveys were designed. One was a face-to-face questionnaire for a pilot study to a number of Go-Car and 
conventional taxi drivers. The other was an online questionnaire using voluntary response sampling method which was distributed through the drivers' WhatsApp group.

The first in-depth interviews were conducted with 5 drivers each from Go-Car and the conventional taxi during November 2018. Each interview lasted around 10-15 min, mostly while using the mobility service. Some of the questions are listed in Appendix 1. Based on this interview results, observations, and literature, the measured variables in the questionnaire were constructed. We used 8 concepts or constructs based on the ERG theory, where each construct has 2 to 3 measured variables. To increase the quality of answers, an incentive of IDR 25 thousand (USD 2) phone credit vouchers for the drivers was provided. The online survey was conducted in Surabaya from March to April 2019 involving 135 respondents for each group. A follow-up interview with 5 Go-Car drivers was then conducted during August 2019 to further explore the meaning of relationship with boss for those gig workers.

For modelling the relationship among the constructs, the Partial Least Square Path Modelling (PLS-PM) method (Hair et al., 2014) was used. We chose this method since we are interested in how well the independent constructs explain the dependent constructs. Furthermore, we are also interested in comparing the paths between two latent variables (constructs) for the two groups, namely, the traditional and gig mobility service workers.

\section{Results and discussions}

\subsection{Qualitative results}

The first phase of in-depth interviews was done as preliminary data gathering prior to quantitative data gathering and further follow-up interviews. The interviews involved 5 Go-Car drivers and 5 traditional taxi drivers ranging from 20 to 68 years old. The demographic characteristics are as follows:

- Go-Car Drivers: $100 \%$ male, age ranged from 27 to 68 (mean: 36, median: 29), on the job experience ranged from 1 day to 7 months.

- Conventional Taxi Drivers: $100 \%$ male, age ranged from 34 to 57 (mean: 44, median: 43), on the job experience ranged from 8 months to 2 years.

With respect to existence needs, we found that the income of Go-Car drivers is remarkably higher than the traditional taxi drivers. One GoCar driver who is 68-year old and retired said that "I do not chase the income; I just do this as a side-line. Since I can earn money, this is better than doing nothing at home. I have and can drive a car anyway. I can go home whenever I feel tired". Another interesting finding is that most Go-Car drivers have their full-time job and see Go-Car as a side-line job. On the other hand, quite a number of the full-time traditional taxi drivers have a side-line job.

With respect to relatedness needs, we could not find a strong contrast between the two groups. One Go-Car driver said "my relationship with superiors and other drivers is good, we help each other through the WhatsApp group. We treat each other like a family". Such a good relationship also exists among the traditional taxi drivers. Most of them think that their job is important because it helps them provide a living for their family. With respect to growth needs, interactions with passengers, including information exchange and emotional labour, are part of their daily learning experience. Go-Car drivers perceived their job as very prospective at least for the next 2 years, despite no basic salary, health insurance, pension scheme as in the case of traditional taxi drivers.

The second phase in-depth interviews were conducted after we got the quantitative results where we found interesting empirical data regarding the relationship with boss for the Go-Car drivers which requires further elaboration to define which party is considered as the boss for the Go-Car drivers. In the conventional taxi case, it is easy to see and understand the employee-boss relationship because it is formally written in the organization's structure. When asked about who the boss is, the Go-Car drivers said "Our boss is the applicator". Applicator refers to the application owner i.e. Go-Jek and represented by the employees working for Go-Jek in the representative offices.

The drivers said "it is easy to contact the applicator" when asked regarding access to the boss. The drivers contact the applicator representatives for several occasions namely changing vehicle's plate number when they change the car used for the service, reporting and returning passengers' goods left behind, reporting abnormality in their system, reporting fictitious orders they received, and settling discrepancies between drivers and the applicator. When asked about their satisfaction toward their relationship with the boss, the Go-Car drivers said "Overall, we are satisfied with the boss". However, some drivers suggested that some aspects can be improved such as transparency in order distribution and the suspension mechanism for the underperforming drivers. One driver mentioned "Now the system works like this. The probability of receiving orders is higher for drivers who are frequently active compared to those who are seldom active. Even though it is not transparently mentioned in the company's policy and code of conduct, based on our experience, it is real". Drivers think that the application is using an algorithm in deciding the order distribution to drivers.

Regarding the co-worker relationship, Go-Car drivers might not acquaintance with one another because the co-worker relationship is not as clearly defined as in conventional taxi. The co-worker relationship among Go-Car drivers were constructed from informal interactions in the unofficial pools and hotspots where they usually gather while waiting for orders. One driver said, "While I was waiting at a hotspot, I usually greeted by other drivers and they ask for my order achievement for the day. This kind of relationship is based on the mutual feeling of being on the same boat".

\subsection{Quantitative results}

The data cleaning process was done after the online survey with 135 respondents where 2 respondents' data points (1 Go-Car and 1 conventional taxi driver) were deleted after being found to be incomplete (see Table 1 for details). The PLS-PM method was used to compute the factor loading from each measured item to its construct. Two items were excluded after this process, i.e. G2 ('I am proud of my job') and G8 ('I think that my job has promising prospects') due to low loadings.

\subsubsection{The measured variables}

Based on the literature and qualitative interview results, we formulated the measured variables for each ERG constructs. Table 2 shows the complete measured variables as stated in the questionnaire.

\subsubsection{Validity and reliability of the measured variables}

As shown in Table 2, all measured variables seem to be sufficiently reliable, i.e. Cronbach's alpha greater than 0.7 , loading values greater than 0.7, and average variance extracted (AVE) greater than 0.5.

The discriminant validity test seems to have acceptable result as shown in Table 3 . The square root of AVE for each construct are mostly larger than the construct's correlation with other constructs.

\subsubsection{The PLS-PM model}

After assessing the validity and reliability of the measured variables and their constructs, they are then used to build the PLS-PM model. The nomological net of the model is shown below in Fig. 1. The PLS-PM model follows the ERG model, where the existence constructs are used to predict the relatedness constructs and further the growth constructs.

It is of interest to look into the percentage of explained variance of the dependent constructs in using the PLS-PM method. As shown in Table 4, the R-square values for the dependent constructs ranges from 0.549 to 0.686 . This means that the independent constructs can reasonably predict the dependent constructs.

Latent variables scores were obtained from the PLS-PM model for 
Table 1

Demographic profile.

\begin{tabular}{|c|c|c|c|c|c|c|c|c|c|}
\hline \multirow[b]{2}{*}{ LABEL } & \multirow[b]{2}{*}{ Gender } & \multirow[b]{2}{*}{ Age (Years) } & \multicolumn{6}{|c|}{ Experience in current job } & \multirow[b]{2}{*}{ Total } \\
\hline & & & $<6$ months & 6-12 Months & 1-2 Years & $2-3$ years & $3-4$ years & $>4$ years & \\
\hline \multirow[t]{11}{*}{ Go-Car } & \multirow[t]{7}{*}{ Male } & $18-25$ & 6 & 3 & 2 & & & & 11 \\
\hline & & $26-33$ & & 8 & 7 & 2 & & & 17 \\
\hline & & $34-41$ & & 3 & 15 & 16 & 2 & & 36 \\
\hline & & $42-49$ & & 1 & 10 & 15 & 3 & 1 & 30 \\
\hline & & $50-57$ & & 1 & 9 & 13 & 4 & & 27 \\
\hline & & $58-65$ & & & 2 & 1 & 2 & & 5 \\
\hline & & $>66$ & & & 2 & 1 & & & 3 \\
\hline & \multirow[t]{3}{*}{ Female } & $34-41$ & & 1 & 1 & & & & 2 \\
\hline & & $42-49$ & & & 1 & & & & 1 \\
\hline & & $58-65$ & & & 1 & & 1 & & 2 \\
\hline & TOTAL & & 6 & 17 & 50 & 48 & 12 & 1 & 134 \\
\hline \multirow[t]{11}{*}{ Conventional } & \multirow[t]{6}{*}{ Male } & $18-25$ & & & 1 & & & & 1 \\
\hline & & $26-33$ & & 1 & 5 & 1 & & & 7 \\
\hline & & $34-41$ & & 1 & 26 & 9 & & & 36 \\
\hline & & $42-49$ & & & 19 & 18 & 1 & & 38 \\
\hline & & 50-57 & & & 9 & 16 & 6 & & 31 \\
\hline & & $58-65$ & & & & 4 & & & 4 \\
\hline & \multirow[t]{4}{*}{ Female } & $18-25$ & & & 1 & & & & 1 \\
\hline & & $26-33$ & & & 3 & & & & 3 \\
\hline & & $34-41$ & & & 5 & & & & 5 \\
\hline & & $42-49$ & & & 5 & 3 & & & 8 \\
\hline & TOTAL & & 0 & 2 & 74 & 51 & 7 & 0 & 134 \\
\hline
\end{tabular}

Table 2

Latent and measured variables along with their codes and reliability.

\begin{tabular}{|c|c|c|c|c|c|c|}
\hline Constructs & Indicators & Code & Loadings & $\begin{array}{l}\text { Loadings } \\
\text { squared }\end{array}$ & $\begin{array}{l}\text { Cronbach's } \\
\text { alpha }\end{array}$ & $\begin{array}{l}\text { Average Variance Extracted } \\
\text { (AVE) }\end{array}$ \\
\hline \multirow{3}{*}{$\begin{array}{l}\text { Working } \\
\text { satisfaction }\end{array}$} & I feel free working here & E1 & 0.949 & 0.901 & & \\
\hline & I think that I can control my working time & E2 & 0.931 & 0.867 & 0.899 & 0.833 \\
\hline & I feel safe working here & E3 & 0.855 & 0.730 & & \\
\hline \multirow[t]{3}{*}{ Income satisfaction } & I think I have a decent pay from my job & E4 & 0.890 & 0.792 & & \\
\hline & I am satisfied with the current salary system & E5 & 0.877 & 0.768 & 0.821 & 0.737 \\
\hline & $\begin{array}{l}\text { I am satisfied with the current incentive system/fringe } \\
\text { benefit }\end{array}$ & E6 & 0.806 & 0.650 & & \\
\hline \multirow[t]{3}{*}{ Relation with peers } & I have the opportunity to have close friends & $\mathrm{R} 1$ & 0.823 & 0.678 & & \\
\hline & $\begin{array}{l}\text { I think that there is a mutual respect among my fellow } \\
\text { workers }\end{array}$ & $\mathrm{R} 2$ & 0.806 & 0.649 & 0.731 & 0.649 \\
\hline & I think that I can help my fellow workers & R3 & 0.787 & 0.620 & & \\
\hline \multirow[t]{3}{*}{ Relation with boss } & I think that my superiors/company respect my job & R4 & 0.943 & 0.889 & & \\
\hline & I think that it is easy to talk openly with my superiors & R5 & 0.954 & 0.909 & 0.908 & 0.845 \\
\hline & I think that my company/superiors trust me & R6 & 0.859 & 0.739 & & \\
\hline \multirow{3}{*}{$\begin{array}{l}\text { Relation with } \\
\text { family }\end{array}$} & My family is happy that I work here & R7 & 0.937 & 0.879 & & \\
\hline & My family is proud that I work here & R8 & 0.922 & 0.851 & 0.886 & 0.815 \\
\hline & I think that I can support my family through my job here & R9 & 0.845 & 0.714 & & \\
\hline \multirow[t]{3}{*}{ Self-growth } & I enjoy working here & G1 & 0.892 & 0.797 & & \\
\hline & I am proud of my job & $\mathrm{G} 2$ & NA & NA & 0.750 & 0.800 \\
\hline & I think that my job helps improve my self confidence & G3 & 0.897 & 0.804 & & \\
\hline \multirow{3}{*}{$\begin{array}{l}\text { Competence } \\
\text { growth }\end{array}$} & I think that my job helps improve my communication skills & G4 & 0.879 & 0.772 & & \\
\hline & I think that I learn a number of new skills when working & G5 & 0.706 & 0.498 & 0.781 & 0.690 \\
\hline & $\begin{array}{l}\text { I think that I have the opportunity to apply my skills in my } \\
\text { job }\end{array}$ & G6 & 0.895 & 0.800 & & \\
\hline \multirow[t]{3}{*}{ Long-term growth } & I think that I can contribute to society at large & G7 & 0.895 & 0.802 & & \\
\hline & I think that my job has promising prospects & G8 & NA & NA & 0.722 & 0.782 \\
\hline & $\begin{array}{l}\text { I think that my job makes this city more comfortable to live } \\
\text { in }\end{array}$ & G9 & 0.873 & 0.762 & & \\
\hline
\end{tabular}

Note that all loadings are highly significant, p-value $<0.001$.

both Taxi and Go-Car group. As shown in Table 5, the scores for Go-Car are generally higher for all constructs. Since the latent variable scores do not follow Gaussian distribution, the non-parametric Wilcoxon test was used to compare the median values for the two groups. It appears that the median values for Go-Car group are significantly higher than that of the Taxi group on all constructs. This means that the Go-Car drivers gave remarkably higher values on all questions in the survey than the Taxi drivers did.

A further comparison test is made for all arrows between the constructs for each group. Fig. 2 shows which arrow is statistically significant at 0.1 level or less for each group. The numbers on the arrow are the coefficient value and the p-value in parenthesis. Here one can see which relationship that exists in both groups, one group but not the other, or do not exist in both groups.

Fig. 3 below shows the overview for all the four possibilities. These four quadrants also simultaneously address the question of 'what difference does the gig mobility service make in the workers' human needs structure?'

\subsection{Type 1: the common traits}

This is to address the question on what both Go-Car and Taxi drivers 
Table 3

Constructs discriminant validity.

\begin{tabular}{|c|c|c|c|c|c|c|c|c|}
\hline & $\begin{array}{l}\text { Working } \\
\text { satisfaction }\end{array}$ & $\begin{array}{l}\text { Income } \\
\text { satisfaction }\end{array}$ & $\begin{array}{l}\text { Relation with } \\
\text { peers }\end{array}$ & $\begin{array}{l}\text { Relation with } \\
\text { boss }\end{array}$ & $\begin{array}{l}\text { Relation with } \\
\text { family }\end{array}$ & $\begin{array}{l}\text { Self- } \\
\text { growth }\end{array}$ & $\begin{array}{l}\text { Competence } \\
\text { growth }\end{array}$ & $\begin{array}{l}\text { Long-term } \\
\text { growth }\end{array}$ \\
\hline $\begin{array}{l}\text { Working } \\
\text { satisfaction }\end{array}$ & 0.913 & & & & & & & \\
\hline $\begin{array}{l}\text { Income } \\
\text { satisfaction }\end{array}$ & 0.747 & 0.858 & & & & & & \\
\hline $\begin{array}{l}\text { Relation with } \\
\text { peers }\end{array}$ & 0.735 & 0.609 & 0.806 & & & & & \\
\hline Relation with boss & 0.762 & 0.676 & 0.789 & 0.920 & & & & \\
\hline $\begin{array}{l}\text { Relation with } \\
\text { family }\end{array}$ & 0.781 & 0.643 & 0.827 & 0.798 & 0.903 & & & \\
\hline Self-growth & 0.815 & 0.728 & 0.736 & 0.795 & 0.769 & 0.895 & & \\
\hline $\begin{array}{l}\text { Competence } \\
\text { growth }\end{array}$ & 0.732 & 0.595 & 0.685 & 0.706 & 0.680 & 0.831 & 0.831 & \\
\hline Long-term growth & 0.780 & 0.666 & 0.679 & 0.760 & 0.688 & 0.846 & 0.850 & 0.884 \\
\hline
\end{tabular}

Note that the diagonal entries are square-root of AVE, the off-diagonal entries are the correlation between the constructs.

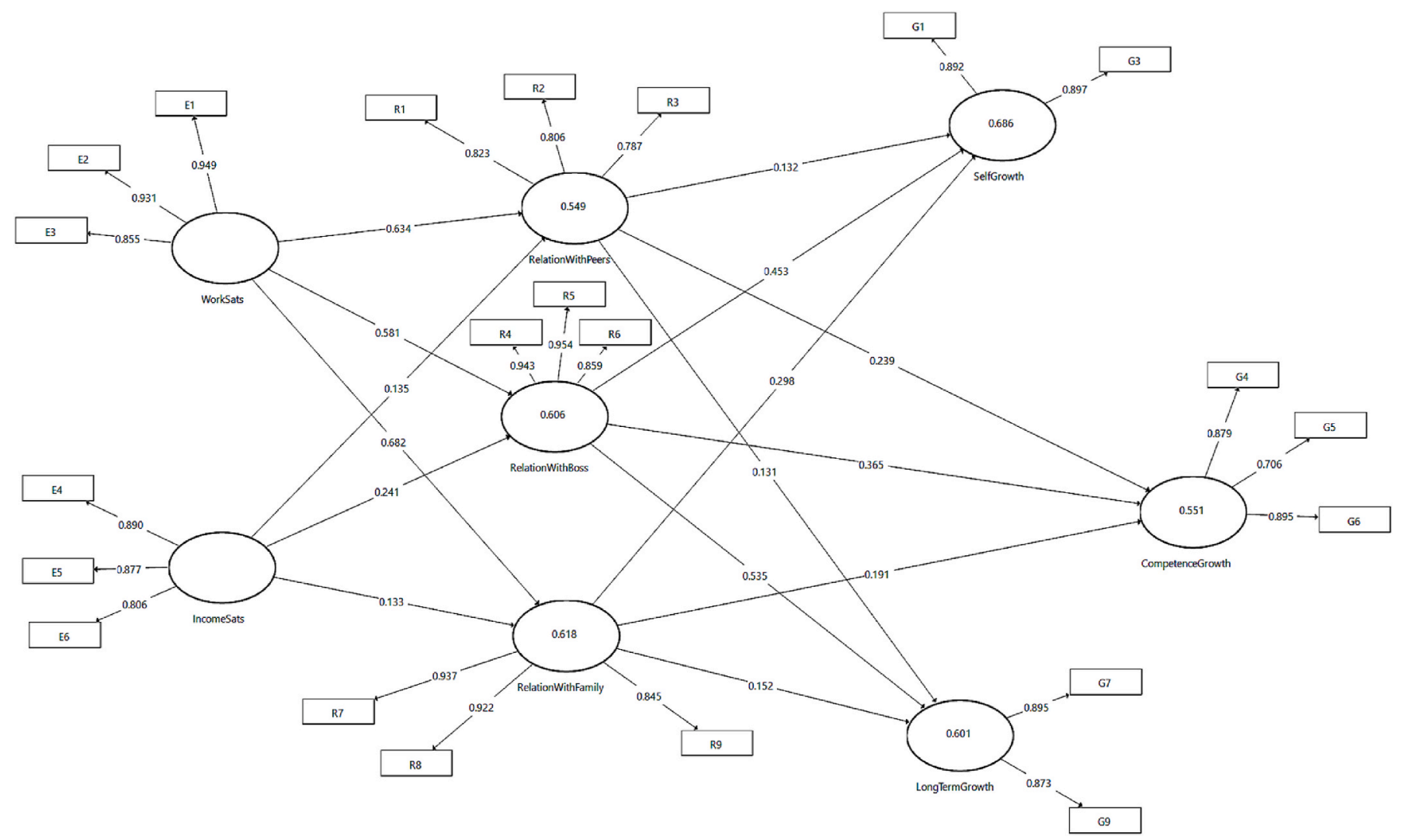

Fig. 1. Overall PLS-PM model for both Taxi and Go-Car.

Table 4

Constructs R-squares.

\begin{tabular}{|c|c|c|c|c|}
\hline \multirow[b]{2}{*}{ Dependent construct } & \multirow[t]{2}{*}{ R Square } & \multirow[t]{2}{*}{ R Square Adj. } & \multicolumn{2}{|c|}{$\begin{array}{l}95 \% \text { bias-corrected } \\
\text { confidence interval }\end{array}$} \\
\hline & & & lower CL & upper CL \\
\hline Relation with peers & 0.549 & 0.546 & 0.463 & 0.621 \\
\hline Relation with boss & 0.606 & 0.603 & 0.527 & 0.663 \\
\hline Relation with family & 0.618 & 0.616 & 0.513 & 0.701 \\
\hline Self-growth & 0.686 & 0.682 & 0.603 & 0.751 \\
\hline Competence growth & 0.551 & 0.546 & 0.444 & 0.627 \\
\hline Long-term growth & 0.601 & 0.596 & 0.505 & 0.674 \\
\hline
\end{tabular}

have in common in terms of worker-needs structure. There are two main findings.

- Work satisfaction is positively associated with relationship with peers and family. Working flexibility is of interest in today's dynamic and more demanding jobs. It includes schedule flexibility, compressed workweek, part time, and telecommuting. The findings show that both Go-Car and Taxi drivers feel free, safe and flexible working here which is associated with a good opportunity to have close friends and mutual respect with their fellow friends. This can be explained by the fact that work flexibility enhances relationships with peers and family. Flexibility can be set as both formal and informal arrangements considering human resources and organizational setting (Kossek et al., 2006). Both companies (i.e., Go-Jek and Conventional Taxi) have policies to support flexible jobs. The adoption of flexible 
Table 5

Two groups non-parametric latent score statistical test.

\begin{tabular}{|c|c|c|c|c|c|}
\hline & & \multicolumn{2}{|c|}{ Median } & \multirow{2}{*}{$\begin{array}{l}\text { Wilcoxon test value } \\
\text { (Chi-sq approx., df } \\
=1 \text { ) }\end{array}$} & \multirow[t]{2}{*}{ p-value } \\
\hline & & Taxi & $\begin{array}{l}\text { Go- } \\
\text { Car }\end{array}$ & & \\
\hline \multirow[t]{2}{*}{ Existence } & $\begin{array}{l}\text { Working } \\
\text { satisfaction }\end{array}$ & 50.0 & 88.8 & 190.48 & $<.0001$ \\
\hline & $\begin{array}{l}\text { Income } \\
\text { satisfaction }\end{array}$ & 48.7 & 63.8 & 148.32 & $<.0001$ \\
\hline \multirow[t]{3}{*}{ Relatedness } & $\begin{array}{l}\text { Relation with } \\
\text { peers }\end{array}$ & 54.0 & 80.1 & 136.32 & $<.0001$ \\
\hline & $\begin{array}{l}\text { Relation with } \\
\text { boss }\end{array}$ & 50.0 & 87.1 & 180.32 & $<.0001$ \\
\hline & $\begin{array}{l}\text { Relation with } \\
\text { family }\end{array}$ & 56.1 & 84.0 & 142.09 & $<.0001$ \\
\hline \multirow[t]{3}{*}{ Growth } & Self-growth & 50.0 & 86.3 & 142.60 & $<.0001$ \\
\hline & $\begin{array}{l}\text { Competence } \\
\text { growth }\end{array}$ & 54.6 & 82.8 & 82.83 & $<.0001$ \\
\hline & $\begin{array}{l}\text { Long-term } \\
\text { growth }\end{array}$ & 50.0 & 75.0 & 119.36 & $<.0001$ \\
\hline
\end{tabular}

jobs as family-friendly policies may contribute to the reduced work-family conflicts.

The online platform work may be seen as a flexible job. Flexible job and schedule are related to job satisfaction, commitment and performance, and decrease turnover. A study by Allen (2001) involving 522 global employees as participants has found that family-supportive initiative was significantly related with family-friendly benefits offered by the company and perceived family support (Allen, 2001). Work environment plays an important role in determining employee responses to family-friendly benefit policies. Flexible work arrangements such as part-time, flexitime, and flexplace have given employees more control over where and when they work. Nonetheless, employees should consider proactive availability and strategic self-presentation techniques to reduce any potential negative feedback, as highlighted by Van Dyne, Kossek and Lobel (2007). Higher employee morale, job satisfaction, and more collegial environment will be promoted as well.

Related to family life, flexible working hours can promote and also facilitate work-life balance. According to Shagvaliyeva and Yazdanifard (2014), the work-life balance may yield reduced stress and increased human wellbeing in any organizations. Both work performance and family quality may be enhanced (Voydanoff, 2005). Schedule flexibility, here, is a work arrangement whereby employees are allowed to decide the time of day they start and stop their tasks or jobs (Baltes et al., 1999). This study has been confirmed with 20 larger U.S. corporations who have applied alternative work schedules. The schedule flexibility is highly increased due to its importance to family and individual matters. It may be applied to attend plays, be a volunteer at the community and more importantly to work in a company. According to Kossek et al. (1999), schedule flexibility aims to accommodate individual needs in order to promote competitive edge in recruitment and to develop a customer-oriented practice (Kossek et al., 1999). It has been confirmed through a study at a large midwestern telecommunications company which had adopted flexible, extended leaves of absence, and part-time jobs. It involved approximately 1000 managers as participants.

Balancing the work and quality of life is a critical challenge for any organization. Flexible working time allows employees to place their personal needs ahead of work needs. Sometimes, it creates psychological administrative headaches for managers (Kossek et al., 1999). Moreover, it leads to variation of daily schedules and increases the need to manage co-worker conflicts. Difficulty in managing service levels is another challenge for flexible working time. With regard to long-term relationships, companies may consider promoting flexible schedules which leads to higher employee morale and job satisfaction, and more collegial environment.

- Relationship with boss is positively associated with self-growth and long-term growth. This shows the importance of being treated or trusted well. Good relationship between employer/boss and employee brings job satisfaction to both parties and leads to the growth of company business (Xesha et al., 2014). Growth of a company refers to a sustainable business, it is a long-term orientation. Better relationships with employers through challenging and difficult times will address self-belongingness. Struggles, resources and best practices should be shared among stakeholders.

\subsection{Type 2: the conventional mobility service}

This is to understand what taxi drivers have that Go-Car drivers do not, in terms of worker-needs structure. There is only one finding.

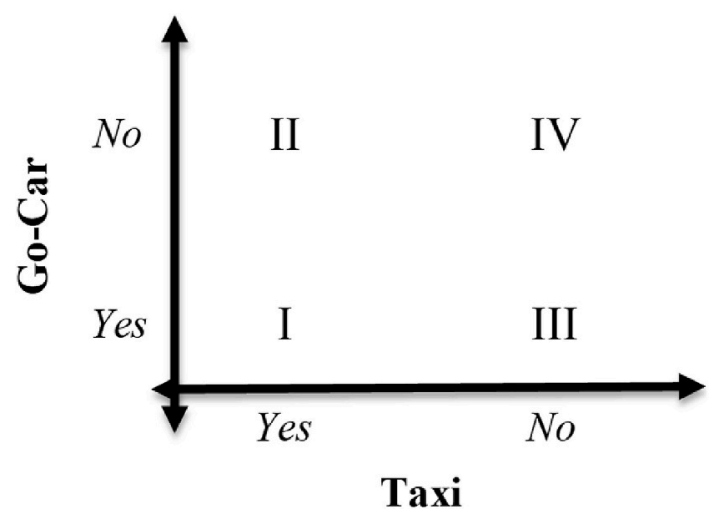

Fig. 3. The four types of worker-needs structure.
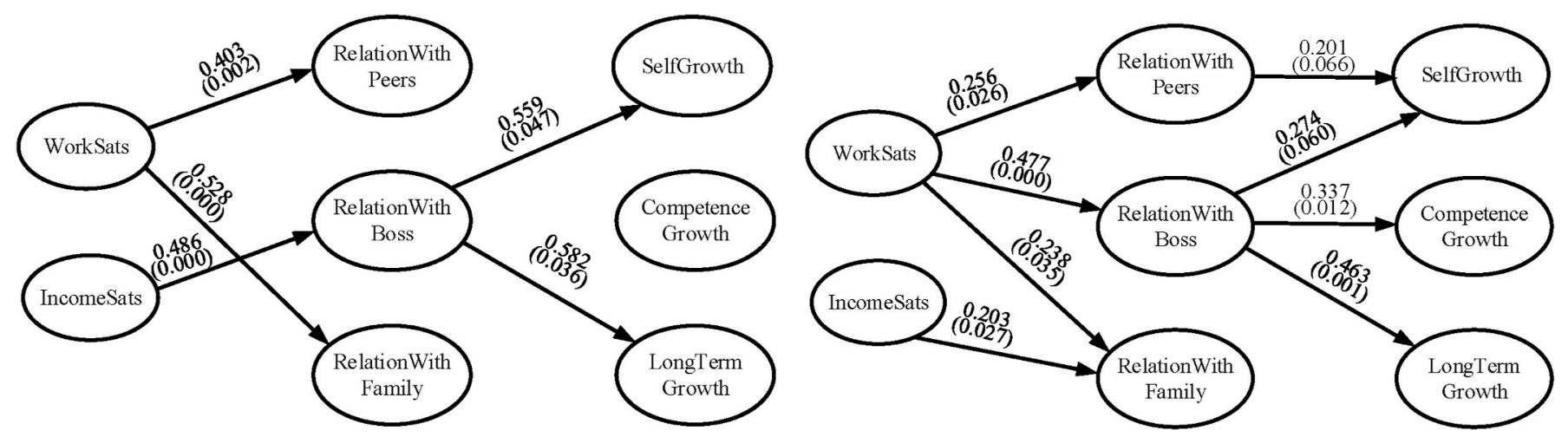

Fig. 2. Contrasting Taxi and Go-Car ERG structure. 
- Income satisfaction is positively associated with relationship with boss. Is this true that respect and trust can also come from how much money one is given? The association between income satisfaction and relationship with boss is found in conventional taxi drivers but not in Go-Car. We suppose that this happened because the conventional taxi drivers are easier to relate themselves with their bosses compared to the Go-Car drivers. Unlike Go-Car, in the conventional taxis case, the bosses are clearly defined within the organization's structure and makes it easier for drivers to relate themselves with the bosses. We suppose that the better compensation received by the drivers will improve the relationship with the boss. From our observations, the conventional taxi drivers were given a better compensation scheme which includes variable commission, medical insurance, family education scholarship, and temporary lodging, while the Go-Car drivers only received $80 \%$ of their total fare without other benefits.

\subsection{Type 3: the gig mobility service}

This is to find out what do Go-Car drivers have that Taxi drivers do not, in terms of worker-needs structure. Interestingly, there are several findings here.

- Work satisfaction is positively associated with relationship with boss. This raises the question if working for the app is better than working for the human/physical boss. It seems that the tech-enabled flexibility contributes to higher trust and respect. Categorized as gigworkers, Go Car drivers have better schedule flexibility as a benefit in working (Kuhn and Maleki, 2017) compared to the conventional taxi driver do. The nature of the worker-boss relationship in gig-economy is not as strict as traditional organization. The Go-Car drivers seem to have a better bargaining position as they own the main asset (car), they are given freedom to express their thoughts to the application's management ("boss"). The drivers are not expected to commit to only one application, our interviews showed that some drivers are registered to more than one ride-hailing applications simultaneously. Having such control and freedom should give the Go-Car drivers better work satisfaction. Go-Car uses an algorithm to decide how the customers' orders are distributed among drivers where drivers with high customer ratings tend to get more orders. This algocracy can be considered as a control mechanism to ensure quality control (Jabagi et al., 2019).

- Income satisfaction is positively associated with relationship with family. This can probably be explained by the contextual factors that quite many of the drivers have to support their family or relatives. In other words, the higher the income the Go-Car drivers have, the better they can help their dependants. The Go-Car drivers we interviewed said that they are satisfied with their income although it is currently lower than what they received during the early inception of Go-Car. A 4 years-experienced Go-Car driver mentioned that he is thankful that his car leasing has been paid off which helped him to be more flexible in driving Go-Car. On the other hand, some drivers must work extra-long hours to be able to pay the lease. Many of the Go-Car drivers have to support their family's finances which can explain that the better the income satisfaction is associated with better support for family.

- Relationship with peers is positively associated with self-growth. It seems that social life may contribute to self-development. Based on our interview, Go-Car drivers' peer relationship is found to be quite strong since they are connected through chat groups where they can support each other by sharing important information such as hotspots, traffic reports, and updates. Unlike in conventional taxis, GoCar drivers usually are not acquaintances, but they can easily mingle among drivers while waiting for orders in a hotspot. The connection among drivers is claimed to raise from the sense of unity in the profession and they come up with a slogan "Salam Satu Aspal" which emphasizes that they are working on the same asphalt road and must support each other. From this peer relationship, drivers can grow their knowledge as the drivers came from various backgrounds of previous professions.

- Relationship with boss is positively associated with competence growth. This can be explained by the fact that professional life leads to better mastery of skills needed in the profession itself, that is, competence. Go-Car offers ways for the drivers to address their complaints and suggestions through customer service, call centre, and social media. The company also regularly invites drivers to join training that would help them improve safety, comfort, and driving skill when delivering services to the customers. The algocracy implemented by Go-Car also positively responded by drivers as they strive to give the best service and getting 5-star rating which will give them a better chance of getting higher income. The drivers are aware that the customers can either praise or criticize some aspect of the service such as vehicle cleanliness, punctuality, driver politeness, route choice, driving skill, and communication skill. Client interaction, in this case interaction with passengers, seems to satisfy workers need for relatedness as was also found by (Rockmann and Ballinger, 2017). For different types of online platform workers, the meaning of management constructs will vary (Kuhn and Maleki, 2017).

\subsection{Type 4: the inconclusive}

What do both Go-Car and Taxi drivers not have in terms of workerneeds structure? Here, we do not have enough evidence to say that the relationships exist. We highlight three main points for those inconclusive relationships, i.e., between income satisfaction and relationship with peers, between relationship with peers and competence growth, longterm growth, and between relationship with family and growth (self-growth, competence growth, long-term growth).

\section{Conclusion}

The aim of this paper was to compare and contrast the perceived psychological experience of the traditional versus gig mobility service workers with respect to their human needs structure. The ERG theory was used in combination with in-depth interviews and observations to develop the constructs and their respective measured variables. Having compared the two groups statistically, we categorized our findings into four quadrants, highlighting what both have and do not have, as well as what one group has but not the other. It was found that the gig mobility service resulted in not only more relationships among the constructs, but also generally higher perceived well-being for the workers.

It seems that the gig mobility service has so far been promising in meeting workers human needs despite its long-term uncertainty, such as health insurance, old-age benefits, and other long-term benefits. Along with the rapid development of information technology and internetbased services, workspace and opportunities related to gig mobility services such as Go-Car will be wide open. In other words, with respect to today's digital economy era, the gig economy should not be underestimated. Gig-workers such as Go-Car drivers fit into casualization of work and informalization of the formal business which offers more flexibility, faster service, and updated real-time information.

This research is primarily limited in three ways. First, it may not be generalized easily given the local Asian contexts in one city in the given period of study which was before the Covid-19 pandemic. The use of our voluntary response sampling method may contribute to non-respondent bias. In other words, the applicability of the results in different gig economy settings should consider, among others, those factors. Second, we have neither tested all propositions as suggested in the ERG theory (Alderfer, 1969) nor explored other possible relationship structures such as the interaction (moderation) effects and mediation mechanisms of the latent and/or measured variables. Third, our sample size for the follow-up interview to confirm findings from the quantitative data 
analysis could have been larger despite the fact that we received good enough responses. Nevertheless, this research can be considered among the few studies on understanding in which way the technology has changed the mobility service actors seen as workers, rather than sellers or users.

\section{CRediT authorship contribution statement}

Markus Hartono: Conceptualization, Formal analysis, Writing original draft, Project administration, Supervision, Funding acquisition. Hendry Raharjo: Methodology, Validation, Writing - review \& editing, Software, Data curation. I Made Ronyastra: Visualization, Investigation, Resources.

\section{Declaration of competing interest}

The authors declare that they have no known competing financial interests or personal relationships that could have appeared to influence the work reported in this paper.

\section{References}

Alderfer, C.P., 1969. An empirical test of a new theory of human needs. Organ. Behav. Hum. Perform. 4, 142-175.

Allen, T.D., 2001. Family-supportive work environments: the role of organizational perceptions. J. Vocat. Behav. 58 (3), 414-435. https://doi.org/10.1006/ jvbe.2000.1774.

Ashford, S.J., Caza, B.B., Reid, E.M., 2018. From surviving to thriving in the gig economy: a research agenda for individuals in the new world of work. Res. Organ. Behav. 38, 23-41. https://doi.org/10.1016/j.riob.2018.11.001.

Baltes, B.B., Briggs, T.E., Huff, J.W., Wright, J.A., Neuman, G.A., 1999. Flexible and compressed workweek schedules: a meta-analysis of their effects on work-related criteria. J. Appl. Psychol. 84 (4), 496-513. https://doi.org/10.15446/rcp. v25n1.56276.

Berger, T., Chen, C., Frey, C.B., Frey, C.B., 2018. Drivers of disruption? Estimating the Uber effect. Eur. Econ. Rev. 110, 197-210. https://doi.org/10.1016/j. euroecorev.2018.05.006.

Davlembayeva, D., Papagiannidis, S., Alamanos, E., 2020. Sharing economy: studying the social and psychological factors and the outcomes of social exchange. Technol. Forecast. Soc. Change 158 (March), 120143. https://doi.org/10.1016/j. techfore.2020.120143.

Geissinger, A., Laurell, C., Öberg, C., Sandström, C., 2019. How sustainable is the sharing economy? On the sustainability connotations of sharing economy platforms. J. Cleaner Prod. 206. https://doi.org/10.1016/j.jclepro.2018.09.196.

Geissinger, A., Laurell, C., Sandström, C., 2018. Technological forecasting \& social change digital disruption beyond Uber and Airbnb - tracking the long tail of the sharing economy. Technol. Forecast. Soc. Change. https://doi.org/10.1016/j. techfore.2018.06.012. Article in(February).

Goldkind, L., Mcnutt, J.G., 2018. Vampires in the technological mist: the sharing economy , employment and the quest for economic justice and fairness in a digital future. Ethics Soc. Welfare 1-13. https://doi.org/10.1080/ 17496535.2018.1512139, 0(0.

Hair, J.F.J., Hult, G.T.M., Ringle, C.M., Sarstedt, M., 2014. A Primer on Partial Least Squares Structural Equation Modeling. Long Range Planning, vol. 46. SAGE Publication, Los Angeles. https://doi.org/10.1016/j.lrp.2013.01.002.

Hon, A.H.Y., 2012. Shaping environments conductive to creativity: the role of intrinsic motivation. Cornell Hosp. Quart. 53 (1), 53-64. https://doi.org/10.1177/ 1938965511424725.
Jabagi, N., Croteau, A.M., Audebrand, L.K., Marsan, J., 2019. Gig-workers' motivation: thinking beyond carrots and sticks. J. Manag. Psychol. 34 (4), 192-213. https://doi. org/10.1108/JMP-06-2018-0255.

Kossek, E.E., Barber, A.E., Winters, D., 1999. Using flexible schedules in the managerial world: the power of peers. Hum. Resour. Manag. 38 (1), 33-46. https://doi.org/ 10.1002/(SICI)1099-050X(199921)38:1<33::AID-HRM4>3.0.CO;2-H.

Kossek, E.E., Lautsch, B.A., Eaton, S.C., 2006. Telecommuting, control, and boundary management: correlates of policy use and practice, job control, and work-family effectiveness. J. Vocat. Behav. 68 (2), 347-367. https://doi.org/10.1016/j. jvb.2005.07.002

Kuhn, K.M., Maleki, A., 2017. Micro-entrepreneurs, dependent contractors, and instaserfs: understanding online labor platform workforces. Acad. Manag. Perspect. 31 (3), 183-200. https://doi.org/10.5465/amp.2015.0111.

Lim, W.M., 2020. Sharing economy: a marketing perspective. Australas. Market J. https://doi.org/10.1016/j.ausmj.2020.06.007.

Paundra, J., van Dalen, J., Rook, L., Ketter, W., 2020. Ridesharing platform entry effects on ownership-based consumption in Indonesia. J. Clean. Prod. 265, 121535 https:// doi.org/10.1016/j.jclepro.2020.121535.

Pavlou, P.A., Gefen, D., 2004. Building effective online marketplaces with institutionbased trust. Inf. Syst. Res. 15 (1) https://doi.org/10.1287/isre.1040.0015.

Roberts, A., Zietsma, C., 2018. Working for an app: organizational boundaries, roles, and meaning of work in the "on-demand" economy. Res. Sociol. Org. 57, 195-225. https://doi.org/10.1108/S0733-558X20180000057008.

Rockmann, K.W., Ballinger, G.A., 2017. Intrinsic motivation and organizational identification among on-demand workers. J. Appl. Psychol. 102 (9), 1305-1316. https://doi.org/10.1037/apl0000224.

Rousseau, V., Salek, S., Aubé, C., Morin, E.M., 2009. Distributive justice, procedural justice, and psychological distress: the moderating effect of Coworker support and work autonomy. J. Occup. Health Psychol. 14 (3), 305-317. https://doi.org/ $10.1037 / \mathrm{a} 0015747$.

Schor, J.B., 2017. Does the sharing economy increase inequality within the eighty percent?: findings from a qualitative study of platform providers. Camb. J. Reg. Econ. Soc. 10 (2), 263-279.

Setiawan, S.R., Ika, A., 2018. Tiap Tahun, go-Jek Sumbang Rp 9,9 Triliun ke perekonomian Indonesia. https://ekonomi.kompas.com/read/2018/03/22/132621 926/tiap-tahun-go-jek-sumbang-rp-99-triliun-ke-perekonomian-indonesia.

Shagvaliyeva, S., Yazdanifard, R., 2014. Impact of flexible working hours on productivity. J. Appl. Psychol. 4, 20-23. https://doi.org/10.1037/00219010.62.4.463.

Singh, B., Selvarajan, T.T., Solansky, S.T., 2019. Coworker influence on employee performance: a conservation of resources perspective. J. Manag. Psychol. 34 (8), 587-600. https://doi.org/10.1108/JMP-09-2018-0392.

Sinintya, W., 2019. Jangan Kaget! Transaksi Gojek Capai Rp 177,5 T pada 2018. http s://www.cnbcindonesia.com/tech/20190124162928-37-52241/jangan-kaget-tran saksi-gojek-capai-rp-1775-t-pada-2018.

Sutherland, W., Jarrahi, M.H., 2018. The sharing economy and digital platforms: a review and research agenda. Int. J. Inf. Manag. 43 (July), 328-341. https://doi.org/ 10.1016/j.ijinfomgt.2018.07.004.

Van Dyne, L., Kossek, E., Lobel, S., 2007. Less need to be there: cross-level effects of work practices that support work-life flexibility and enhance group processes and grouplevel OCB. Hum. Relat. 60 (8), 1123-1153. https://doi.org/10.1177/ 0018726707081657.

Van Emmerik, I.J.H., Euwema, M.C., Bakker, A.B., 2007. Threats of workplace violence and the buffering effect of social support. Group Organ. Manag. 32 (2), 152-175. https://doi.org/10.1177/1059601106286784.

Voydanoff, P., 2005. Toward a conceptualization of perceived work-family fit and balance: a demands and resources approach. J. Marriage Fam. 67 (4), 822-836. https://doi.org/10.1111/j.1741-3737.2005.00178.x.

Xesha, D., Iwu, C.G., Slabbert, A., Nduna, J., 2014. The impact of employer-employee relationships on business growth. J. Econ. 5 (3), 313-324. https://doi.org/10.1080/ 09765239.2014.11885007.

Young, M., Farber, S., 2019. The who, why, and when of Uber and other ride-hailing trips: an examination of a large sample household travel survey. Transport. Res. Part A 119, 383-392. https://doi.org/10.1016/j.tra.2018.11.018. 